\title{
The Work Ethic of Teachers and Employees in SMA Negeri 1 Semendawai Barat
}

\author{
Andi Wijaya ${ }^{1 *}$, Bukman $\operatorname{Lian}^{2}$, Alhadi Yan Putra ${ }^{2}$ \\ ${ }^{1}$ SMA Negeri 1 Semendawai Barat \\ ${ }^{2}$ Universitas PGRI Palembang \\ *Corresponding author. Email: andiwi2405@gmail.com
}

\begin{abstract}
The aims of this research are to see how teachers at SMA Negeri 1 Semendawai Barat works. The method used in this study is qualitative research methods. The data technique used are observation and interview techniques. The informants in this study are the Principal and Teacher of SMA Negeri 1 Semendawai Barat. The results of the research include the ability to carry out the duties of the teachers in planning teaching, formulating teaching objectives and planning teaching and learning activities, but in selecting and developing teaching materials is still lack. At the teacher's initiative in implementing the teaching and learning process, opening lessons, delivering subject matter and closing lessons are good. In the quality of work results where the teacher in assessing teaching and learning outcomes, the ability to compose questions, provide test scores for learning outcomes and process the results of the assessment are good. In communication aspect, a teacher and staff members have skills such as interviewing skills, material explaining skills, leadership skills for small group discussions, skills for classroom management and skills for small group and individual teaching.
\end{abstract}

Keywords: Work Ethic, Teachers and Employees, Quality.

\section{INTRODUCTION}

Education is an effort that is carried out on purpose or with awareness that is carried out in order to develop the potential of students through learning at school in the hope that these students get a positive change from the previous state through the learning process at school.

School is a place to carry out formal education from an educational unit. This school is a means that facilitates students to gain useful knowledge, skills and attitudes through the teaching and learning process carried out by the teacher with the aim that these students get useful behavior changes and changes in more advanced thinking patterns [1].

The education process will run well if every existing component such as school principals, teachers, staff, curriculum and school facilities and infrastructure can run well and can be used optimally. So, it can be said that the educational process will run well if all the components involved in the institution can run optimally because if one of the components is lacking or incomplete, such as inadequate facilities, or teachers who teach just as is, of course the educational process will not go well. The existence of teachers and staff as well as adequate learning facilities certainly greatly supports the smooth implementation of the learning process at the school, for this reason, those who are responsible for changing the knowledge or attitudes of students are all components in the school through the teaching and learning process that goes well. Therefore, the good work ethic of teachers and other staff is expected to be able to bring positive behavior changes for students through coaching from teachers who really teach well for students.

Problems that are often encountered in institutions, especially in schools today, where teachers are very difficult to develop the potential of their students, changes in student behavior that are expected from the learning process in schools are sometimes not in accordance with the expectations of the parents of students. While various kinds of questions arise for parents of students, why the learning process that students receive from school does not provide positive changes in student behavior.

Related to this work ethic, Nata admits that the success of an organization is very much dependent on the work ethic of its employees. This shows that this work ethic plays a very important role in determining the progress of an institution or not. Why is this work ethic important because this work ethic is closely related to the personality, behavior and level of a person's personality where everyone has an internal form to help him realize who is them a. Work ethic is a fundamental characteristic 
of someone who is accustomed to solving problems and the problems they face and how to take the next steps to solve these problems or problems in terms of personality, world, and the work he does [2].

A teacher's work ethic is like a teacher's point of view, meaning seeing the problems faced by students in class so that a teacher must be able to find solutions so that students can learn the lessons they teach easily accept them. Because of this learning problem, almost all teachers find it difficult to instill awareness in students so that they can learn well and accept what the teacher teaches them.

This situation is of course experienced by various institutions including educational institutions, as it is known that the quality of education in Indonesia is still unable to compete with other countries, especially in the field of technology. This is still found in various schools, especially in Sumatra Selatan where schools still use technology as part of the learning media which is not optimal, especially in existing districts. The less optimal utilization is because the facilities provided by the school are not in accordance with current developments. In addition, the teacher's ability to master the media as a learning tool for students is still lacking.

For example, in SMA Negeri 1 Semendawai Barat, it can be said that the use of technology as a means of learning for students has not been achieved as a whole because schools still have not got the media in every subject that can be used as a learning tool. This was revealed in the researcher interview before conducting research with several professions. According to them, the lack of technical facilities owned by the school caused the use of teaching materials in schools to not run well due to various limitations.

The problems in SMA Negeri 1 Semendawai Barat are closely related to the morale of teachers and staff in carrying out their duties. The ability of teachers to apply teaching methods, develop learning tools, and understand the curriculum in the teaching and learning process, as well as the current staff at SMA Negeri 1 Semendawai Barat, where they are often late and leave early. In addition, the teacher only teaches what is in the book so that what is in the book is taught to students. Facing these problems, SMA Negeri 1 Semendawai Barat continues to seek ways to improve teachers' abilities in carrying out their duties, especially in the development and production of teaching materials for teachers. This means that teachers and staff at SMA Negeri 1 Semendawai Barat currently need to improve their ability to determine the teaching methods that will be used to develop teaching materials that attract students' interest in good learning.

Lack of discipline on the part of employees in carrying out their duties, delayed promotion proposals for teachers and staff and timeliness in fulfilling institutional duties. Tasks are defined as the attitude of a person or group who wants to obey predetermined rules. In relation to work, the concept of timeliness or work discipline is an attitude and behavior that shows employee obedience to organizational rules [3].
The quality of work of teachers and employees at Senior High School 1 of Semendawai Barat is currently considered to be less than optimal because the tasks carried out are not in accordance with existing instructions or mistakes often occur in completing work. The quality of work emphasizes the results or results of a job rather than contributing to the standard of achieving the final results of staff work in SMA Negeri 1 Semendawai Barat.

To improve the quality of work results, it is influenced by organizational factors and personal factors. Organizational factors include the reward system, quality of supervision, workload, values and interests, as well as the physical conditions of the work environment. Among the various organizational factors, the most important is the reward system factor, where this factor will be given in the form of a salary, bonus, or promotion. In addition, the second organizational factor that is equally important is the quality of supervision, where a subordinate can get job satisfaction if his boss is more competent than himself [4].

In the absence of communication between colleagues, it was found that teachers and staff always work separately, especially if something goes wrong at work, they don't want to ask other staff. Communication is an essential part of professional life. This is easy to understand because poor communication can have a considerable influence on organizational life, for example conflicts between employees, and vice versa, good communication can increase mutual understanding, cooperation and job satisfaction. Because those who work together in an organization to achieve goals are a group of people of different characters, open communication must be well developed.

Improving the quality of learning requires efforts to improve the quality of the learning program as a whole, because the essence of the quality of learning is the quality of the implementation of pre-designed work programs. To improve the quality of work programs, information is needed about the results of the quality assessment of the previous program. In the framework of updating work programs, including program evaluation activities of ongoing or ongoing programs, it needs to be implemented properly. To be able to develop a better program, the results of the previous program evaluation are an indispensable reference [5].

To support teaching and learning activities, SMA Negeri 1 Semendawai Barat has teachers who are qualified in their fields as teachers and have teaching experience. Some of the teachers at SMA Negeri 1 Semendawai Barat are in the process of completing their master's education. Based on the description above, the authors are interested in conducting research on "Work Ethic Of Teachers And Employees at SMA Negeri 1 Semendawai Barat". Work ethic is a determinant of productivity, because work ethic is a view to assessing the extent to which we do a job and continue to strive to achieve the best results in every job. Work to develop a productive work ethic that includes not only individual productivity but also the productivity of society as a 
whole [6]. The word in Indonesian comes from the Greek word ethos which means "a sign used to describe belief as a guideline or standard / principle (ideals) that guide a person. Search for Nation or Ideology community". The Greek word ethos was later transferred to the English word ethos. Ethos forms the root word ethicos, which means morality, which denotes moral character. The plural form is ta ethik and is the origin of the word ethics in English. Ethics is then translated into ethics in Indonesian [7].

Ethics and morals the terms ethics and morals are often confused. In many scriptures, it is rare to find a writer who uses these terms consistently. But in this article, the writer tries to find the contents of the two terms. Ethics comes from the Greek word "ethos" which means habit or character, while morality comes from the Latin "mos" (plural) which means a way of life or habit [8]. In contrast to morality which means enthusiasm or inner motivation.

Body posture is essentially a tendency to make pleasant and unpleasant statements from someone, which reflects how they feel about people, objects or events in their environment. Professional or professional attitudes such as organizational obligations, professional involvement / employee engagement and job satisfaction have multiple meanings for managers [9]. On the one hand, an important outcome that the new manager wants to improve on. On the other hand, this is a symptom of another potential problem.

Based on the above limitations, the work ethic of teachers can be used as the main reference in the world of education in Indonesia, where the work ethic of teachers in a school organization is absolutely necessary to improve the efficiency and effectiveness of the process of implementing learning tasks in school teaching units. Efforts to improve the quality of education can be made. Thus, the Indonesian nation can adjust to other developed countries in the Asian region in particular and the world in general.

A high teacher work ethic will determine the success of the business and learning process in schools. Therefore, this problem is interesting to consider and analyze in a school organization that involves various decisions, including the decisions of the teachers themselves. Regarding this work ethic, argues that "work ethic is the perspective and attitude of a person who assesses what work means as a part of life to improve his life". In addition, Atmowirio explains more specifically the definition of work ethics as follows: "Work ethics is the basis for improving the performance / performance of all civil servants" [10]. Referring to these limitations, the work ethic of the teacher in carrying out their duties at school. In this case, the work ethic of the teacher is perceived in relation to the implementation of professional duties.

\section{METHODS}

The research was conducted at SMA Negeri 1 Semendawai Barat. The situation and situation chosen was the work ethic of teachers at SMA Negeri 1 Semendawai Barat which covered a very broad context, involving people, time, location, and process. This is done to obtain data accuracy and avoid data that does not actually occur at the research location. In a social research setting, a variety of information is found which comes from the research subject under study. Determination of sources of information in this study adheres to four characteristics, namely: context (relating to atmosphere, circumstances, or setting), behavior, events, and processes. Before going to the research location, the researcher is expected to understand the research background first. In addition, researchers strive to maintain the independence and professionalism of researchers and must prepare themselves physically and mentally and uphold a high sense of accountability.

This research uses a qualitative research approach in which qualitative research as a scientific method is often used and carried out by a group of researchers in the field of social sciences, including education. A number of reasons are also put forward, the point is that qualitative research enriches the results of quantitative research. Qualitative research is carried out to build knowledge through understanding and discovery. A qualitative research approach is a process of research and understanding based on methods that investigate social phenomena and human problems.

Data collection is a systematic and standard procedure for obtaining the required data. It should be explained that data collection can be done based on experience. Indeed, it can be studied data collection methods commonly used, but how to collect data in the field and how to use these techniques in the field [11]. So, to obtain data related to the discussion of the work ethic of SMA Negeri 1 Semendawai Barat teachers.

\section{RESULTS AND DISCUSSION}

The data presented in this study are the results of interviews and direct observations / observations of the work ethic of teachers in SMA Negeri 1 Semendawai Barat. Interviews were conducted to obtain data on mastery of material, structure, concepts, and scientific mindsets that support the subjects being taught, teacher understanding of learning theory, and learning methods. While the observations that the authors make are observations of the work ethic of the teacher which includes the learning program and the learning process.

The work ethic of the teacher in the learning process can be determined on the achievement of a teacher in carrying out its functions during a certain period of time as measured by three indicators, namely: (1) Ability to develop lesson plans; (2) Ability to carry out learning; (3) the ability to assess learning achievement and (4) the ability to carry out follow up on the results of the learning achievement assessment of students.

To find out the level of work ethic of SMA Negeri 1 Semendawai Barat teachers, researchers conducted interviews with parties related to the subject to be 
studied, namely interviews with the principal of SMA Negeri 1 Semendawai Barat.

Based on the results of a brief interview with the Principal of SMA Negeri 1 Semendawai Barat, the results of the interview were obtained, namely, the support provided by the principal of SMA Negeri 1 Semendawai Barat related to the work ethic of SMA Negeri 1 Semendawai Barat teachers, among others: providing facilities and infrastructure. By providing adequate facilities and infrastructure, it will improve teaching and learning activities that are better, more effective, and in accordance with the objectives to be achieved. In addition, academic qualifications and educator certifications. A professional teacher must have the appropriate academic qualifications and have followed the educator certification. Teachers who do not have academic qualifications and teacher certification are expected to continue their education again.

From the results of direct interviews with the Principal of SMA Negeri 1 Semendawai Barat, it is known that the support provided by the principal is related to the work ethic of classroom teachers, namely teachers who are not yet undergraduate are encouraged to continue studying again, and teachers who have not been certified to take teacher certification. That is because a teacher at SMA Negeri 1 Semendawai Barat can be categorized as a professional teacher if he already has a teacher academic qualification. Even the Principal of SMA Negeri 1 Semendawai Barat also strives for teachers who are not yet undergraduate to get scholarships and can continue their studies.

Teachers who teach at SMA Negeri 1 Semendawai Barat all have a teaching schedule of at least 24 lesson hours per week; always make annual program; promissory note; syllabus and lesson plans; self-made which is adjusted to the prevailing curriculum development; conduct daily evaluations; remedial and enrichment programs; as well as developing teaching materials and there are several teachers who are conducting Classroom Action Research.

Work ethic is a key concept in the world of education in Indonesia, where the work ethic of teachers in a school organization is very important to increase the efficiency and effectiveness of the process of implementing learning tasks in school units as measured by indicators, namely:

\section{Making Planning in Teaching}

From the results of observations and interviews with informants, it can be seen that the SMA Negeri 1 Semendawai Barat must adhere to the curriculum by presenting teaching materials that do not meet the needs of students. In addition, teaching materials must also be adapted to the type and environment of students from background and have not been implemented in the teaching and learning process, so that students themselves still have difficulty learning by getting alternative teaching materials apart from school supplies such as books and texts that are difficult to find.

With the existence of teaching materials that are in accordance with the curriculum and fit the needs of students, learning does not depend on text sources that are difficult to obtain. The teacher makes the learning process a source of many and comprehensive references. Educators' insight into experiences and knowledge becomes deeper and broader and develops teaching materials so as to create effective learning interactions between students and educators. This is because students can respect the teacher more.

This is explained from the results of interviews with researchers with the principal of Administration at SMA Negeri 1 Semendawai Barat, saying that: "Teachers of SMA Negeri 1 Semendawai Barat have not maximally utilized planning in teaching so they have not been able to provide more free time to study independently. so that dependence on teachers is reduced and it can make it easier for students to understand every competency that must be achieved.

\section{Implementation of Teaching and Learning Process}

From the results of the research carried out it can be said that the implementation of the Teaching and Learning Process in SMA Negeri 1 Semendawai Barat in compiling a learning plan can be said to be good. This can be seen in the ability of SMA Negeri 1 Semendawai Barat teachers in systematically presenting subject matter, organizing student activities in class, using predetermined learning media / practice tools (and material), using selected learning resources (in the form of books), modules, computer programs and the like), motivating students in various positive ways, concluding learning and effectively and efficiently using time only in sufficient categories. While the indicators of the ability to open lessons with the right method, apply predetermined learning methods and procedures, interact with students using communicative language, and provide questions and feedback, find and strengthen student acceptance and learning is already in a good category.

However, these good indicators still need to be improved to be good or even very good. A teacher is expected to understand the topic systematically. By understanding the topic systematically, students will easily assimilate and study the material being taught.

In addition, a teacher is required to be able to use learning media and materials that have been determined. The use of the correct method will also determine the effectiveness and efficiency of learning. Learning should be done with less lecture and teacher-centered methods, and with more emphasis on student interaction, using a variety of methods will greatly help students achieve their learning goals.

The presence of the teacher in the learning process

Punctuality is the ability of SMA Negeri 1 Semendawai Barat teachers to complete their assignments correctly and on time and dare to take risks with decisions or actions they take.

Based on the research results, it turns out that due to the punctuality of the teachers of SMA Negeri 1 Semendawai Barat, they get good grades, but still carry out their mission in all circumstances; Always prioritizing the interests of the office above the interests 
of oneself, others or groups; Dare to take risks based on decisions or actions taken. Safeguarding and / or safeguarding the assets that have been entrusted properly is also a good thing. However, there are still teachers who leave earlier than other teachers, are less concerned with organizational goals and less courageous to take risks and are less careful in maintaining offices and infrastructure so that there are elements that we do not know where they are.

Based on the analysis of the teacher's presence in the learning process at the SMA Negeri 1 Semendawai Barat, it can be said that it is good.

\section{Assessing Teaching and Learning Outcomes}

From the results of the research conducted it can be said that the ability of SMA Negeri 1 Semendawai Barat teachers in assessing learning outcomes can be said to be good. This can be seen from the ability of SMA Negeri 1 Semendawai Barat teachers in carrying out the assessment, analyzing the results of the assessment (based on the level of difficulty, peculiarity, validity and reliability), concluding clearly and logically the results of the assessment (misinterpretation of the tendency of the assessment results, student achievement levels) and report assessment results only in the sufficient category. While the indicators of the ability to write questions/assessment tools are in accordance with predetermined indicators/job criteria, verify answers/provide test scores for learning outcomes based on indicators/job criteria. work that has been determined, assesses learning outcomes against predetermined assessment criteria, results assessment process and corrects questions/assessment tools that are in the correct category. However, these good indicators still need to be improved so that they are even better.

The results of research on the ability of teachers of SMA Negeri 1 Semendawai Barat in assessing learning outcomes in the form of: a. Prepare questions / assessment tools in accordance with predetermined performance indicators/criteria; Do an assessment; Check responses/provide test scores for learning outcomes based on predetermined performance indicators/criteria; Evaluating learning outcomes against predetermined evaluation criteria; Processing evaluation results; Analyze the results of the assessment (based on the level of difficulty, distinguishing power, validity and reliability); Summarize the results of the assessment clearly and logically (eg: interpretation of assessment trends, student achievement levels); Prepare a report on the results of the assessment and refine the questions/assessment tools. The ability of SMA Negeri 1 Semendawai Barat teachers in assessing learning outcomes in general is considered sufficient.

\section{Teacher Skills}

Teachers as workers must have skills that include mastery of subjects, mastery of professionalism and teacher guidance, mastery of adaptation tools and personality to carry out their duties. apart from the fact that the teacher must be a dynamic and developing person. This is in accordance with the provisions of Law Number 20 of 2003 concerning the National Education
System which requires educators and education personnel: (1) to create an educational environment that is meaningful, fun, creative, dynamic, and dialogical; (2) has a professional commitment to improve quality of education, and (3) provide an example and maintain a good reputation for trusted institutions, professions and functions. The hope in this law shows that there is a paradigm shift in the teacher learning model, which was originally a source of information for students and is still dominant in class activities, has changed to a paradigm that positions the teacher as a facilitator in the learning process and there is always an interaction between teacher and students and students and students in class. This fact forces teachers to always improve their abilities, especially by setting an example, strengthening their will and developing students' creativity in the learning process.

Job performance is the result of work carried out by SMA Negeri 1 Semendawai Barat teachers in carrying out the assigned tasks. In general, the work performance of SMA Negeri 1 Semendawai Barat teachers is influenced by the skills, abilities, experience, and seriousness of the public officials involved.

Based on the analysis of the skills of teachers in SMA Negeri 1 Semendawai Barat above, it can be said that it is good.

\section{CONCLUSION}

Based on the results of research and discussion of the work ethic of teachers in SMA Negeri 1 Semendawai Barat in general, it is generally quite good. This is reflected in the dimensions of the existing teaching and learning process as follows: 1) the ability to carry out tasks where teachers plan in teaching, formulate teaching goals and plan teaching and learning activities, but in selecting and developing teaching materials is still lacking; 2) on the initiative where the teacher in implementing the teaching and learning process, opening lessons, delivering lesson material and closing lessons is good according to the rules; 3 ) for the timeliness of the teacher's presence in the learning process, teaching timeliness, teaching time effectiveness and teacher craft in teaching is good, and 4) the quality of work, where the teacher assesses teaching and learning outcomes, the ability to compile questions / assessment tools, check answers / give learning outcomes test scores and processes the results of the assessment is good, 5. Communication where a teacher and staff members have good explaining skills.

\section{ACKNOWLEDGMENT}

Our deepest gratitude goes to Teachers in SMA Negeri 1 Semendawai Barat, Chancellor of Palembang PGRI University, Director of the Postgraduate Program of PGRI Palembang University and the Education Management Study Program of PGRI Palembang University, who have supported us in doing this extraordinary thing. This project is funded 
independently. We also want to thank our Education Management friends who helped us a lot in a short time frame to complete this project.

\section{REFERENCES}

[1] Triguno. (2002). Pengantar Pendidikan [Introduction to Education]. Jakarta: PT Raja Grafindo Persada.

[2] Nata, A. (2001). Paradigma Pendidikan Islam: Kapita Selekta Pendidikan Islam [Paradigm of Islamic Education: Capita selecta of Islamic education]. Jakarta: Grasindo.

[3] Tebba, S. (2003). Membangun Etos Kerja Dalam Perspektif Tsawuf. Cetakan I [Building a Work Ethic in Tsawuf's Perspective. Prints I]. Bandung: Pustaka Nusantara.

[4] Hamalik, O. (2001). Proses Belajar Mengajar [Teaching and Learning Process]. Jakarta: Bumi Aksara.

[5] Sedarmayanti. (2011). Manajemen Sumber Daya Manusia [Human Resource Management]. Bandung: PT. Refika Aditama.

[6] Ginting, D. (2016). Panduan Menjadi Karyawan Cerdas [Guide to Being a Smart Employee]. Penerbit: Pt. Elex Media Kompurindo.

[7] Tasmara, T. (2002). Membudidayakan Etos Kerja Islami [Cultivating an Islamic Work Ethic]. Jakarta: Gema Insani Press.

[8] Wibowo. (2014). Perilaku Dalam Organisasi [Behavior in Organizations]. Jakarta: Rajawali Pers.

[9] Atmowirio, S. (2000). Manajemen Pendidikan [Education Management]. PT Ardadizya, Jakarta.

[10] Arikunto, S. (2013). Prosedur Penelitian suatu Pendekatan Praktek [Research Procedure a Practice Approach]. Jakarta: PT Rineka Cipta. 